\title{
MEMPERTIMBANGKAN KEMBALI KONSEP TENTANG TUHAN, MANUSIA, DAN AQL DALAM FILSAFAT AL-KINDĪ DAN SEYYED HOSSEIN NASR
}

\author{
Shofiyullah Muzammil \\ Fakultas Ushuluddin dan Pemikiran Islam UIN Sunan Kalijaga \\ Yogyakarta \\ Email:Shofiyullah22@gmail.com
}

\begin{abstract}
In human history, since the first thought, it has known the existence of forces that overcome humans, a person who is considered almighty, and brings good and bad and can grant prayer and to human desires. From this thought, concepts emerged about God. God is central and at the core of everything that exists. In the monotheistic religious tradition the issue of God always gets the main attention and occupies the top position of various other religious issues. This paper aims to explore aspects of the views of Islamic philosophers about the concepts of divinity, humanity and reason. It also summarizes their various interpretations of the metaphysical concept from a philosophical point of view which is the harmonization of scientific traditions. The concept of divinity above has contributed constructively to religious thinking. However, this can not be separated from weaknesses and criticism.

Dalam sejarah manusia, sejak pertama pemikiran, sudah mengetahui adanya kekuatan-kekuatan yang mengatasi manusia, suatu yang dianggap Maha Kuasa, dan mendatangkan kebaikan maupun keburukan serta dapat mengabulkan doa dan ke inginan manusia. Dari pemikiran tersebut kemudian muncul konsep-konsep tentang Tuhan. Tuhan merupakan sentral sekaligus inti dari semua yang ada. Dalam tradisi keagamaan monoteis Persoalan ke-Tuhan-an selalu mendapat perhatian utama dan menempati posisi teratas dari berbagai persoalan keagamaan lainnya. Tulisan ini bertujuan menelisik aspek-aspek pandangan para filsuf Islam tentang konsep ketuhanan, manusia dan akal. Juga sekaligus merangkum berbagai interpretasi mereka mengenai konsep metafisik dari sudut pandang filsafat yang merupakan harmonisasi tradisi keilmuan. Konsep ketuhanan di atas telah memberikan sumbangan pemikiran yang
\end{abstract}


konstruktif terhadap pemikiran keagamaan. Akan tetapi hal tersebut tidak lepas dari kelemahan dan kritik.

Keywords: Konsep; Tuhan; Manusia; Akal dan Metafisik

\section{Pendahuluan}

Buku $A$ History of God menunjukkan pada kita bahwa dimensi kesejarahan konsep tentang Tuhan. Manusia hidup dalam varian etnik dan budaya, maka terbentuk pula lah berbagai macam variasi dalam konsep tentang Tuhan ${ }^{1}$. Bagi Karen Armstrong, manusia adalah makhluk sejarah, oleh karena itu nama-nama Tuhan juga ditemukan dalam wacana sejarah dan pemikiran agama. ${ }^{2}$ Sejak pertama sejarah pemikiran, manusia sudah mengenal serta mengetahui adanya suatu kekuatan-kekuatan yang melebihi kemampuan manusia, suatu yang dianggap mahakuasa, yang kemudian dapat mendatangkan kebaikan ataupun kejahatan bahkan dapat mengabulkan doa dan keinginan. Hal tersebut mengindikasikan bahwa pengetahuan tentang Tuhan sudah sejak dini dan telah dimiliki oleh manusia.

Dipelbagai belahan tempat manusia mengenal adanya kekuatan-kekuatan supranatural, orang Indian Amerika menyebutnya wakan, orenda dan maniti, sedang orang India menyebutnya hari, adapun orang melanesia menyebutnya mana ${ }^{3}$, lain halnya dengan orang Jepang yang menyebutnya kami dan dalam bahasa Indonesia sendiri disebut tuab yang mengacu pada kekuatan-kekuatan tersebut berada pada tempat-tempat tertentu seperti pohon besar, binatang, atau gunung. Rudolf Otto menyebutnya dengan sitilah niminous yakni segenap perasaan dan keyakinan atas adanya Yang Maha Kuasa ${ }^{4}$, sesuatu yang lebih besar

${ }^{1}$ K. Hidayat \& M. W. Nafis, Agama Masa Depan: Persepektif Filsafat Pernial (Jakarta: Paramadina, 1995), 35.

2 A. Kuswanjono, Ketuhanan Dalam Telaah Filsafat Perenial: Refleksi Pluralisme Agama di Indonesia (Yogyakarta: Badan Penerbit Filsafat UGM, 2006), 28.

${ }^{3}$ H. Nasution, Filsafat Agama (Jakarta: Bulan Bintang, 1979), 28.

${ }^{4}$ K. Hidayat \& M. W. Nafis, Agama Masa Depan, 34. 
dan lebih tinggi dan tidak dapat dijangkau dan dikuasai manusia itu, hal demikian merupakan bentuk dasar bagi setiap agama.

Kekuatan-kekuatan gaib yang dimaksud diatas, kecuali dalam agama-agama yang masih primitif, disebut Tuhan. Pembahasan tentang konsepsi-konsepsi ketuhanan yang merupakan salah satu kajian pokok dalam filsafat dianggap penting untuk dilakukan suatu pengkajian yang lebih mendalam.

\section{Al-Kindī}

Pada abad ke-9 penulisan filsafat secara sistematis baru dimulai adapun pada masa sebelumnya kegiatan filosofis hanya terbatas pada penerjemahan karya-karya filsafat Yunani dan Suryani. $^{5}$ Seorang penulis yang mengawali langkah untuk membangun tradisi penulisan filsafat tak lain adalah Al-Kindī atau Alkindus atau nama lengkapnya Abu Yusuf Ya'kub ibn Ishaq ibn Shabbah ibn Imran ibn Ismail Al-Ash'ats ibn Qais Al-Kindī ${ }^{6}$, lahir di Kufah, Iraq sekarang, tahun 801 M, pada masa khalifah harun Al_Rasyid (786-809 M) dari Dinasti Bani Abbas (750-1258 $M)^{7}$. Penisbahan nama Al-Kindī kepada marga atau suku leluhurnya, salah satu suku besar zaman pra- Islam. Al-Kindī lahir dari keluarga bangsawan, terpelajar, dan kaya. Ismail Al-Ash'ats ibn Qais, buyutnya, telah memeluk Islam pada masa Nabi dan menjadi sahabat Rasul. Mereka kemudian pindah ke Kufah. Di Kufah, ayah Al-Kindī, Ishaq ibn Shabbah, menjabat sebagai gubernur, pada masa Khalifah Al-Mahdsi (775-785 M), Al-Hadi (785-876 M), dan Harun Al-Rasyid (786-909 M), masa kekuasaan Bani Abbas (750$1258 \mathrm{M})$. Ayahnya meninggal saat Al -Kindi masih kecil ${ }^{8}$.

${ }^{5}$ Majid Fakhry, Sejarah Filsafat Islam (Bandung: Mizan, 2002) 25.

${ }^{6}$ H. K. Soleh, Filsafat Islam: Dari Klasik. Hingga Kontemporer (Jogjakarta: ArRuzz Media, 2013), 88.

${ }^{7}$ H. K. Soleh, Filsafat Islam, 88.

${ }^{8}$ H. K. Soleh, Filsafat Islam, 89.

TAJDID Vol. 17, No. 1, Januari - Juni $2018 \mid 3$ 
Al-Qifti (1171-1248 M) mengatakan bahwa Al-Kindī sering menerjemahkan buku filsafat, menjelaskan hal-hal yang pelik, dan membuat ringkasan secara canggih atas teori-teorinya. Hal itu dapat dilakukan karena Al-Kindī menguasai secara baik bahasa Yunani dan Syiria, yang tak lain merupakan bahasa induk karyakarya filsafat saat itu. Berkat kemampuannya itu juga, Al-Kindī memiliki kemampuan memperbaiki hasil-hasil terjemahan orang lain, misalnya hasil terjemahan Ibn Na'ima Al Himsi, seorang penerjemah Kristen, atas buku Enneads karya Plotinus (204-270 M); buku Enneads inilah yang di kalangan pemikir Arab kemudian di salahpahami sebagai buku Theologi karya Aristoteles 9.

Pemberian julukan kepada Al-Kindī sebagai "Filosof Arab" adalah karena dia lah satu-satunya filosof muslim keturunan Arab asli yang bermoyang kepada Ya'qub ibn Qahthan yang bermukim di kawasan Arab Selatan. Al-Kindī termasuk filosof Islam yang sangat produktif. Dia telah menulis banyak karya yang meliputi berbagai macam bidang ilmu. Ibnu Nadhim mengatakan bahwa Al-Kindī telah merilis 260 judul karya seperti, Filsafat, Logika ,Kosmologi. Akan tetapi, sedikit saja jumlah karya Al -Kindi yang sampai ke tangan orang-orang setelahnya. Sebagian riwayat mengklaim bahwa karya-karya Al-Kindī hilang semasa kepemimpinan Khalifah Al-Mutawakkil ${ }^{10}$.

Al-Kindī jelas menunjukkan kepada kita bahwa ia tertarik pada pemikiran Aristoteles dan Plato lewat karya-nya. Bahkan kedua filosof itu sering ia sebut dalam karya-karyanya. Al-Kindī melalui terjemahannya mampu mempelajari karya besar Aristoteles yang berjudul Metaphysics serta menuliskan komentarnya atas karya ini. Di luar itu, ternyata Al-Kindī juga menyimpan karya dialog Aristoteles berjudul Eudemus. Tidak hanya cukup sampai pada penulisan komentar atas Metaphysics saja, Al-Kindī juga menulis

\footnotetext{
${ }^{9}$ H. K. Soleh, Filsafat Islam, 89.

${ }^{10}$ Hasan Basri, Filsafat Islam (Jakarta: Direktorat Jenderal Pendidikan Islam Kementerian Agama Republik Indonesia, 2013), 35.
}

4 | TAJDID vol. 17, No. 1, Januari - Juni 2018 
komentar atas karya Aristoteles seperti Categorie, De Interpretatione, Analytica Posteriora dan juga menuliskan komentar atas De Caelio. Tingginya semangat pembelajaran dan pendalaman atas filsafat yang dipunyai Al-Kindī, hal ini jelas menunjukkan pada kita adanya keinginan yang luar biasa tak terhingga untuk memperkenalkan filsafat Yunani kepada para reader pengguna bahasa Arab guna menentang para Teolog ortodoks yang cenderung enggan dan menolak pengetahuan asing ${ }^{11}$. Hasil tulisan Al-Kindī tak lepas dari hasil cerminan komitmen kuatnya pada jalan filsafat dan wacana rasional. Diantara karyanya yang paling menarik adalah risalahnya yang berjudul Al-Hatsts 'ala Ta'allum Al-Falasafah (Anjuran untuk Belajar Filsafat), Fi Al-Falsafah Al-Ula (Filsafat Pertama) dan lain sebagainya. Dalam kerangka filosofis Al-Kindī terlihat banyak sekali mengikuti jejak pemikiran Plato dan Aristoteles.

Al-Kindī dalam paragraph di atas memang dipandang sebagai filosof bangsa Arab pertama karena ia sebagai pencinta kebijaksanaan serta mempunyai metode dan penyelidikan filsafat yang tersistematis. Ia menjadi jembatan penghubung antara pendekatan intelektual dengan disiplin filsafat. Terlebih pada masa itu teologi mu'tazilah menjadi pegangan utama pemerintahan Islam sehingga secara praktis dan pragmatis Al-Kindī mendapat dukungan besar dari tiga orang khalifah Bani Abbas yakni AlMa'mun, Al-Mu'tasim, dan Al-Watsiq. Ketiga Khalifah ini mendukung penuh secara total atas keberlangsungan sistem belajar-mengajar serta kegiatan ilmiah, filsafat, dan sastra. Akan tetapi sayangnya pada masa pemerintahan al-Mutawakil, Al-Kindī mengalami nasib buruk karena khalifah tidak menyetujui atas keberpihakan dan kecenderungannya terhadap paham mu'tazilah, sehingga beberapa konflik terjadi antara dirinya dan penguasa khalifah yang dikemudian hari menyebabkan Al-Kindī mengalami kerugian seperti dipecat dari jabatannya, perebutan perpustakaan Al-Kindiyah yang walau pada akhirnya perpustakaan tersebut

${ }^{11}$ Hasan Basri, Filsafat Islam, 36.

TAJDID vol. 17, No. 1, Januari - Juni $2018 \mid 5$ 
kembali di tangan pemilik aslinya. Al-Kindī juga tidak memperoleh hak-hak istimewanya di istana kekhalifahan ${ }^{12}$.

Kontribusi terbesar yang sebenarnya diberikan Al-Kindi adalah terbukanya pintu-pintu filsafat bagi para ilmuwan muslim. Umat muslim pada zaman dahulu sungguh amat menentang untuk mempelajari ilmu filsafat, karena dikhawatirkan akan menyebabkan berkurangnya rasa hormat kepada Tuhan. Namun, Al-Kindi mencoba untuk membangun nilai filsafat yang baru dan mendesak mereka agar mau dan terbuka dalam menoleransi gagasan-gagasan yang berasal dari luar Islam. Al-Kindi menjembatani kesenjangan antara pendekatan-pendekatan intelektual setengah hati dengan disiplin filsafat yang keras dari rekan-rekan muslim sezamannya. Pendekatan dan sikap inilah yang menghantarkan dirinya diberi gelar faylasof (filsuf) ${ }^{13}$.

\section{Pemikiran Al-Kindī}

Bagi Al-Kindī, filsafat adalah ilmu pengetahuan yang mulia. Filsafatnya tentang keesaan Tuhan selain didasarkan pada wahyu juga proposisi filosofis. Al-Kindī merupakan filosof Islam pertama yang menggagas bukti rasional filosofis tentang Tuhan. Ia berusaha menunjukkan eksistensi Tuhan melalui argumentasi kebaruan (dalil al-baudust). Menurut Al-Kindī, seberapapun luasnya alam semesta maka ia adalah terbatas dan segala yang terbatas tidak mungkin tidak mempunyai awal yang tidak terbatas. Dengan kata lain, alam mestilah mempunyai titik awal dalam waktu ${ }^{14}$. Betapapun jauhnya alam ketika dirunut kebelakang, ia harus dimulai dalam titik temporal tertentu, dan tidak mungkin surut ke belakang secara tak terhingga atau tasalsul.

12 George N. Atiyah, Al-Kindi Tokoh Filosof Muslim (Bandung: Penerbit Pustaka, 1983), 6.

13 Wahyu Murtiningsih, Para Filsuf dari Plato sampai Ibnu Bajjah (Jogjakarta: IRGiSoD, 2013), 270.

14 Zaprulkhan, Filsafat Islam: Sebuah kajian Tematik (Jakarta: Raja Grafindo Persada, 2014), 26.

6 | TAJDID Vol. 17, No. 1, Januari - Juni 2018 
Penetapan unsur-unsur yang menyusun materi fisikal merupakan tahap permulaan persoalan metafisika. Keseluruhan benda yang dapat ditangkap indera merupakan juz'iyah (partikular) dari wujud benda. Menurut Al-Kindī, hal yang terpenting untuk dibicarakan filsafat adalah hakikat yang terdapat dalam benda bukanlah aspek partikular benda-benda itu. Seperti yang telah diketahui pemikiran macam model seperti ini sedikit banyak telah dipengaruhi oleh pembagian benda dalam substansi dan aksidensi terutama sering dikenal dalam filsafat Aristoteles. Apabila dalam filsafat Aristoteles, substansi adalah bahan yang tetap dan aksidensi adalah aspek yang mungkin berubah dari benda, maka Al-Kindī menegaskan bahwa tiap benda mengandung dua hakikat; hakikat juz'iyah yang disebutnya sebagai 'Aniyah dan hakikat kulliyah yang disebut Mahiyah ${ }^{15}$.

Menurut pandanannya, Tuhan tak mempunyai hakikat, baik hakikat secara jur'iyah atau aniyah (sebagian) maupun hakikat kulliyyah atau mabiyah (keseluruhan). Tuhan bukan seperti bendabenda yang mempunyai fisik yang dapat ditangkap indera. Tuhan tidak tersusun dari materi dan bentuk (dari matter dan form). Karena Tuhan tidak memiliki aspek mahiah, maka Tuhan tidak merupakan genus atau species. Dalam pandangan Al-Kindī, Tuhan tidak merupakan genus atau species. Tuhan adalah Pencipta. Tuhan hanya satu, dan tidak ada yang serupa dengan Tuhan ${ }^{16}$. Tuhan dalam pemikiran Al-Kindī adalah al-Haqq al-Awwal dan alHaqq al-Wabid, Yang benar Tunggal dan Ia semata-mata satu. Hanya Ialah yang satu, selain dari Tuhan semuanya mengandung arti banyak. Al-Kindī juga menolak pendapat yang menganggap sifat-sifat Tuhan itu berdiri sendiri. Tuhan haruslah merupakan keesaan mutlak. Bukan keesaan metaforis yang hanya berlaku pada obyek-obyek yang dapat ditangkap indera.

${ }^{15}$ Hasan Basri, Filsafat Islam, 39.

${ }^{16}$ Harun Nasution, Falsafat dan Mistisisme Dalam Islam Cet. 1. Jakarta: Bulan Bintang(1973), 15.

TAJDID vol. 17, No. 1, Januari - Juni $2018 \mid 7$ 
Menurut Al-Kindī, Tuhan tidak memiliki sifat-sifat dan atribut-atribut lain yang terpisah dengan-Nya, tetapi sifat-sifat dan atribut-atribut tersebut haruslah tak terpisahkan dengan Zat-Nya. Pembahasan mengenai sifat Tuhan ini akan dibahas pada paragraf di belakang. Al-Kindī menyatakan bahwa alam dan hukum-hukum yang berlaku di dalamnya, tidak akan mengkin berjalan se-teratur yang terlihat, tanpa ada yang mengedalikannya. Wujud pengendali alam yang menjaganya tetap berada dalam keteraturan tentulah wujud yang maha dan tidak akan mungkin sama dengan yang dikendalikannya. Jika alam dan hukum hukum alam adalah baharu, maka pengendali tidaklah baharu. Jika alam dan hukum-hukum alam merupakan hasil penciptaan, maka pengendali bukanlah wujud yang diciptakan. Sesuatu yang mengendalikan mesti berbeda dengan yang dikendalikannya. Sebab bila antara pengendali dengan yang dikendalikan sama, maka yang akan lahir adalah sebuah ketidak-teraturan. Pengendali yang menjaga keteraturan ini, hanya dapat diketahui melalui pelacakan jejak-jejaknya saja.

Argumentasi yang terakhir ini dikenal dengan illat tujuan. Keteraturan alam dalam pengendalian ini mengarah pada sikap hormat dan kekaguman manusia pada Tuhan yang mengatur dan mengendalikan alam dengan begitu rasional dan harmonis jika direnungkan secara mendalam ${ }^{17}$. Sementara tentang sifat Tuhan, Al-Kindī menyebutkan bahwa sifat Tuhan itu azali, yang tidak berawal dan tidak berakhir. Sifat Tuhan yang azali, juga mencakup pengertian zat yang ada dalam wujudnya tidak tergantung pada lainnya atau bergantung pada sebab ${ }^{18}$. Yaitu zat yang sama sekali tidak bisa dikatakan tidak ada, atau ada pada permulaannya ada, melainkan zat yang ada dalam wujudnya tidak tergantung pada lainnya atau bergantung pada sebab. Dan juga berbeda dengan jisim, zaman maupun gerak, karena setiap jisim pasti ada

${ }^{17}$ Hasan Basri, Filsafat Islam, 41.

18 Harun Nasution, Filsafah dan Mistisme dalam Islam (Jakarta: Bulan Bintang, 1978), 16.

8 | TAJDID Vol. 17, No. 1, Januari - Juni 2018 
kesudahannya, begitupun dengan setiap tempat dan zaman ada kesudahannya, maka semua anasir berjenis demikian itu tidak lah abadi dan azali; menurut Al-Kindī, azali bukanlah suatu jenis melainkan ia adalah suatu yang benar, yang tidak ada kesudahannya, yaitu tuhan Allah. ${ }^{19}$ Ia tidak bergerak, sebab bila dikatakan bergerak berarti ia memerlukan perubahan atau pertukaran arah. Sedangkan yang memerlukan perubahan dan pertukaran arah memerlukan ruang dan waktu. Padahal Allah tidak perlu ruang dan waktu ${ }^{20}$.

Tampak nyata sekali bahwa argumentasi kosmologis sangat mendominasi pemikiran al-Kindī dalam menjelaskan ketuhanan. Al-Kindī menjadikan Allah sebagai Penyebab segalanya dan sekaligus penyebab kebenaran. menjadikan Allah sebagai penyebab segala kebenaran adalah sama saja dengan mengatakan bahwa Allah menjadi penyebab dari semua hal ini. Sebab dari segala sebab itu merujuk hanya kepada Allah. Sebab itu hanya satu, tidak mungkin banyak. Alam semesta dapat berjalan secara teratur tanpa terkecuali karena dasar sebab Dzat yang Satu. Sehingga tampak nyata di hadapan kita bahwa konsep sentral dalam teologi Filsafat Pertama milik al-Kindī berbicara tentang keesaan. Teologi filsafat al-Kindī punya aspek penting; yakni, membuktikan harus ada yang Satu yang Benar (the true one), yang merupakan penyebab dari segala sesuatu dan mendiskusikan kebenaran the True One ini. ${ }^{21}$ Mengenai pembahasan tentang proof evidences alias bukti adanya tuhan, AlKindī menyodorkan lima buah bukti, bukti yang pertama bercorak teologis, sedangkan empat terakhir merupakan argumen-argumen kosmologi yang didasarkan atas pemikiran novitate munde (dalil al-

\footnotetext{
${ }^{19}$ Abu Bakar Aceh, Sejarab Filsafat Islam (Sala: Ramadhani, 1982), 4.

${ }^{20}$ Hasan Basri, Filsafat Islam, 43.

${ }^{21}$ Lihat, Seyyed Hossein Nasr \& Oliver Leamen, Ensiklopedi Tematis Filsafat Islam (ed) (Bandung: Mizan, 2003), 210.
} 
budust) dan tidak langsung berupa penguat atas argumen dari hubungan sebab dan akibat ${ }^{22}$.

Pertama, proof evidences yang didasarkan atas keteraturan atau kerapian alam. Jalan terpenting yang dijalani oleh Al-Kindī untuk membuktikan adanya tuhan ialah dengan cara memperhatikan dengan seksama terhadap alam ini. Menurutnya, alam ini jelas tidak mungkin rapi saat ia pertama kali diciptakan, dan kerapian itu tidak terjadi dengan sendirinya, melainkan kerapian alam ini pasti diciptakan oleh subtansi yang maha kuasa. Jadi alam ini tidak mungkin rapi dan teratur kecuali ada yang mengatur. Kecuali, adanya zat yang tidak nampak, zat yang tidak nampak ini dapat diketahui dari bekas-bekas dan kerapian yang telah ada, demikian juga tampak terlihat pada fenomena suatu kejadian alam yang sedang berlangsung terjadi, maka tidak mungkin secara tiba-tiba maupun kebetulan, melainkan ia mempunyai tujuan-tujuan tertentu. Al-Kindī menegaskan bahwa alam empiris ini tidak mungkin dan terkendali begitu saja tanpa ada yang mengatur dan mengendalikannya. Pengatur dan pengendalinya tetntu yang berada diluar alam dan tidak sama dengan alam. Zat itu tidak terlihat, tetapi dapat diketahui dengan melihat fenomena atau tanda-tanda yang terdapat di alam. Bagi Al-Kindī, hal tersebut menunjukan adanya dzat yang maha kuasa yang dapat mengatur revolusi alam itu sendiri ${ }^{23}$, dzat itulah yang disebut Allah.

Proof evidences kedua, dari hukum sebab akibat, segala sesuatu yang baru pastilah ada yang mengadakannya, tidak ada sesuatu yang muncul ada dengan sendirinya. Atau sebab diciptakannya suatu yang baru berasal dari suatu yang sebelumnya, sebagai contoh: alam ini baru dan diciptakan, tidak mungkin muncul ada dengan sendirinya tanpa ada pencipta. Sebagai bukti atas barunya alam ini adalah alam ini mempunyai batas dari segi benda, benda

\footnotetext{
22 George N. Atiyah, Al-Kindi, 55.

23 Ahmad Hanafi, Pengantar filsafat Islam (Jakarta: Bulan Bintang, 1969), 81.

10 | TAJDID Vol. 17, No. 1, Januari - Juni 2018
} 
dan gerak sangat berkaitan erat, oleh karena itu alam ini ada batasnya karena adanya gerak dan waktu. Al-Kindī kembali menegaskan bahwa segala sesuatu yang ada batasnya pastilah ia dihukumi sebagai sesuatu yang baru ${ }^{24}$. Bahwa, menurutnya, tidak mungkin alam ini mempunyai batas permulaan waktu dan setiap yang mempunyai permulaan akan berkesudahan (mutanahi). Setiap benda pasti ada yang menyebabkan wujudnya dan mustahil benda itu sendiri yang menjadi sebab keberadaannya. Dengan demikian bahwa alam semesta pasti lah baharu dan diciptakan dari tiada oleh yang menciptakannya, yakni Allah.

Proof evidences ketiga dari Al-Kindī diletakkan atas pemikiran ide islam mengenai ke-esaan tuhan, yang dirangkai ke dalam semua wujud dunia adalah bayangan majmuk dan berganda, atau keanekaragaman alam wujud. Kalau kita cermati keadaan alam ini, tampak ada keseragaman dan keragaman di dalamnya. Hal demikian tidak akan mungkin dapat terjadi tanpa adanya penyebab yang menyebabkan, dan penyebab itu sendiri adalah tuhan Allah. Terpadunya keseragaman dan keragaman di atas bukanlah suatu kebetulan belaka, dan sebab (yang menjadi pemicu) itu bukanlah alam sendiri, karena apabila alam sendiri lah yang menjadi sebabnya, itu halnya akan menjadi tidak terhingga dan tak ada habis-habisnya, padahal sesuatu yang tidak berakhir itu tidak mungkin dapat terjadi ${ }^{25}$. Al-Kindī berargumen bahwa tidak mungkin ada keanekaragaman terjadi dengan sendirinya atau secara kebetulan, tetapi pasti lah ada yang menyebabkan atau merancangnya. Akan menjadi mustahil alam itu berdiri sendiri sebagai penyebab adanya dirinya, dan jika alam yang menjadi sebab (Illat')-nya maka akan terjadi sebuah tasalsul (rangkaian) yang tidak akan habis-habisnya. Dengan demikian, harus dapat dipahami dengan benar bahwa yang menjadi penyebab harus berada diluar

${ }^{24}$ A. Hanafi, Theologi Islam (Yogyakarta: Sumbangsih, 1962), 64.

25 Sidi Gazalba, Sistematika Filsafat, Buku III (Jakarta: Bulan Bintang, 1973), 07.

TAJDID Vol. 17, No. 1, Januari - Juni 2018|11 
alam itu sendiri, yakni Zat Yang Maha Baik, Maha Mulia, yang keberadaannya mendahului adanya alam, yang disebut dengan Allah Swt. Al-Kindī menyebut bahwa ada dua sebab atau illat: Pertama, sebab yang sebenarnya dan aksinya ada merupakan ciptaan dari ketiadaan (ibda') ialah Allah Yang Maha Esa, Pencipta Tunggal alam semesta. Kedua, sebab yang tidak sebenarnya, sebab yang menyebabkan sebab-sebab itu sendiri. Sebab ini jelas membutuhkan yang lain tanpa berkesudahan. Ia bukanlah bukanlah sebab yang menciptakan alam ini.

Keempat, proof evidences yang berdasarkan prinsip bahwa sesuatu tidak dapat menjadi sebab dirinya. Agar dapat menjadi demikian, sesuatu tersebut haruslah ada sebelum dirinya (baca: yang di maksud sesuatu disini ialah segala bentuk ciptaan tuhan). Dan untuk membuktikan hal ini Al-Kindī merumuskan empat macam persoalan kemungkinan ${ }^{26}$ yang merupakan sebuah kemustahilan unutk dapat terjadi bagi kemungkinan itu sendiri, yaitu:

a. Sesuatu yang menjadi sebab dari dirinya, ia mungkin berwujud non eksistensi dan esensinya pun juga berwujud non ekistensi.

b. Sesuatu mungkin berwujud non eksisten sedangkan esensinya eksisten.

c. Sesuatu itu mungkin berwujud eksisten sedangkan esensinya non eksisten.

d. Sesuatu itu mungkin berwujud eksisten sedangkan esensinya juga eksisten.

Apabila kita telaah lebih jauh mengenai hukum konteradiksi yang Al-Kindī bagikan di atas, maka tidak ada dalil yang bias dihukumi benar dan salah.

Proof evidences terakhir, dapat ditelusuri dari analogi antara makroksmos dan mikroksmos. Pembuktian ini dilakukan guna

${ }^{26}$ George N. Atiyah, Al-Kindi, 57-58.

12 | TAJDID Vol. 17, No. 1, Januari - Juni 2018 
melihat hal-hal yang sangat kecil sampai hal yang besar, yang tentu itu berada dan melingkupi manusia (baik yang dapat di rasakan oleh indra maupun yang tidak bias), dan semua hal ini ternyata berjalan sebagaimana fungsinya, maka kesimpulannya ini menandakan adanya pengatur yang tidak terlihat. Sebagaimana berfungsinya tubuh manusia yang tertib dan lancar yang mengarahkan kesadaran kita kepada adanya suatu pengatur yang cerdas tidak bisa di lihat, yaitu jiwa. Demikian juga ihwal jalannya alam semesta yang begitu tertib selaras dapat menunjukkan akan adannya pengatur yang maha kuasa yaitu tuhan Allah ${ }^{27}$.

Al-Kindī kemudian menjelaskan mengenai sifat Tuhan. Menurut Al-Kindī, Tuhan memiliki sifat utama di samping sifatsifat yang lainnya, sifat utama yang dimaksud di sini adalah tidak lain melainkan Keesaan tuhan. Esa dalam arti satu, Esa dalam zatNya sekaligus Esa dalam pengetian teori maupun praktek. Sifat inilah yang merupakan sifat khusus bagi-Nya, Tuhan itu satu dalam zatnya dan satu dalam hitungan, oleh karena itu sifat Tuhan menjadi Yang Maha Kuasa, Yang Maha Tahu, Yang Hidup, Yang Qadim dan seterusnya, dan Tuhan itu bukan lah suatu wujud melainkan Dia-lah zat yang menciptakan wujud ${ }^{28}$. Al-Kindī juga menggunakan dalil naqli dan aqli sebagai dasar ketika menjelaskan masalah Keesaan ini. Sebagamana para mutakallimin, baik mu'tazilah maupun asy'ariyah, dalil naqli yang di gunakan yaitu surah al-ikhlas dari ayat 1-5, sedangkan dalil naqli yang digunakan berbeda dengan dengan dua golongan tersebut namun pada intinya sama, yaitu upaya untuk mensucikan tuhan. Namun tampak bahwa sebebanrnya Al-Kindī justru lebih condong kepada pemikiran mu'tazilah $^{29}$.

27 M.M. Syarif. History «f Muslim Philosophy, Terj. Fuad Fakhruddin (Bandung: CV Diponegoro, 1970). 101.

28 Roger Grudy, Promosses De L'Islam, Terj. H.M. Rosyidi (Jakarta: Bulan Bintang, 1982), 150.

${ }^{29}$ A. Hanafi, Theologi, 86.

TAJDID Vol. 17, No. 1, Januari - Juni 2018 13 
Al-Kindī memberikan perbedaan yang cukup jelas antara keesaan mutlak dan keesaan metaforis atau keesaan yang muncul sebab adanya esensi dan yang disebabkan oleh bilangan-bilangan. Apa yang di maksud dengan keesaan mutlak adalah Tuhan itu sendiri, sedangkan yang di maksud keesaan metaforis ialah semua ciptaan-Ny. Ciptaan-Nya ini memiliki atribut-atribut tertentu yang menunjukkan pada keberagaman, sedang keberagaman selalu menunjuk pada bilangan dan setiap bilangan akan selalu menunjuk kepada suatu konsep kuantitatif, padahal kuantitas-kuantitas itu justru mempunyai atribut-atribut yang pasti melekat tak terpisahkan darinya. Atribut-atribut yang lekat dari kuantitas itu akan selalu dapat terbagi-bagi dan Tuhan tidaklah demikian.

Senada dengan hal ini, Fuad Al-ahwani menjelaskan arti suatu yang bersifat mutlak dan suatu metaforis dengan istilah simple yakni sesuatu yang hakiki dan suatu yang majazi. Suatu yang hakiki adalah suatu yang menurut subtansinya ia tidak akan berubah menjadi banyak walau disebabkan oleh apapun juga, tidak akan pernah berubah walau disebabkan oleh subtansinya sendiri maupun oleh hal ihwal yang ada di luar subtansinya. Sedangkan yang majazi ialah sesuatu dalam arti bisa disebutkan pada apa saja, baik satu dalam kalimatnya berkaitan dengan matematika, dalam kaitannya dengan ilmu alam, atau dengan segala kaitannya di alam wujud $^{30}$.

Ketika ingin menekankan sifat Keesaan Tuhan Al-Kindī seringkali menyatakan bahwasanya Tuhan tidak akan pernah dapat disamakan dengan ciptaan-Nya, hal ini dikarenakan sesuatu Yang Esa sejati bukan lah sesuatu yang dapat dipahami, Dia bukan suatu unsur, bukan genus, bukan lah species, bukan jiwa, tidak berupa pikiran, tidak berjumlah, ataupun partikular, juga tidak berupa sesuatu yang bisa dimasukkan ke dalam konsep-kosep. Yang Esa sejati itu adalah yang tak terbentuk, tak berukuran, dan juga tidak

30 Ahmad Fuad Al-Alhwani, Filsafat Islam, Terj. Sutarji Caulzoum Bakhri (Jakarta: Pustaka Firdaus, 1985), 102.

14 | TAJDID Vol. 17, No. 1, Januari - Juni 2018 
dapat digambarkan dengan suatu uraian yang bias diterapkan pada apapun yang dipahami oleh akal. Tuhan tidak akan pernah dapat dilukiskan oleh suatu sifat apapun kecuali Keesaan-Nya itu sendiri. Jadi, setiap keesaan selain-Nya hanyalah kata-kata, kecuali keesaanNya yang mutlak,dan murni ${ }^{31}$. Dari kategori-kategori di atas yang telah dipaparkan oleh Al-Kindī, dapat kita lihat dan ketahui bersama bahwa terdapat kesamaan dengan konsep aliran mu'tazilah, bahwa sifat tuhan adalah sama dengan esensi-Nya. Juga, menolak sifat-sifat positif apapun atas dasar bahwa hal itu akan meniadakan Keesaan Tuhan.

Jiwa atau roh manusia juga merupakan salah satu pembahasan Al-Kindī. Ia merupakan filosof Muslim pertama yang membahas hakikat roh secara terperinci. Al-Kindī membagi roh atau jiwa manusia itu menjadi 3 (tiga) daya, yaitu;

a) daya berpikir (al-quwwah al-'aqliyah),

b) daya marah (al-quwwah al-gadhabiyah), dan

c) daya syahwat (al-quwwah al-syahwaniyah).

Daya berpikir itu disebut akal. Sementara akal terdiri dari tiga tingkat;

a. Akal yang masih bersifat potensial (al-quwwah),

b. Akal yang telah keluar dari potensial menjadi aktual (AlFi'l), dan

c. Akal yang telah mencapai tingkat kedua dari aktualitas (al'ql al-tsany), akal kedua.

Pembagian Al-Kindī atas akal menjadi tiga, yakni akal yang bersifat potensial, akal yang telah keluar dari sifat potensial menjadi aktual, dan akal yang telah mencapai tingkat kedua dari aktualitas. Akal yang bersifat potensial, menurut Al-Kindī, tak bisa mempunyai sifat aktual, jika tak ada kekuatan yang menggerakkannya dari luar. Oleh karena itu, Sedangkan akal yang bersifat potensial tidak akan menjadi aktual jika tidak ada kekuatan

${ }^{31}$ George N. Atiyah, Al-Kindi, 64.

TAJDID Vol. 17, No. 1, Januari - Juni 2018|15 
yang menggerakannya dari luar, yang mempunyai wujud tersendiri diluar jiwa manusia. Akal tersebut adalah akal yang selamanya aktualis (al - 'aql al-ladzi bi al-fi'l abadan), dan ini memiliki ciri-ciri sebagai berikut:
a. merupakan Akal Pertama,
b. selamanya dalam aktualitas,
c. merupakan species dan genus,
d. membuat akal potensial menjadi aktual berpikir, dan
e. tidak sama dengan akal potensial tetapi lain dari padanya

Menurut Al-Kindī, masih ada satu macam akal lagi, yakni akal yang selamanya dalam aktualitas ${ }^{32}$

\section{Seyyed Hossein Nasr}

Pemikirannya banyak dijadikan sebagai rujukan maupun perbandingan oleh kalangan pemikir-pemikir Islam maupun dunia Barat, khususnya tentang sejarah dan tradisi pemikiran yang berkembang di dunia Timur dan Barat. Ia dilahirkan pada tanggal 17 April 1933 di Taheran-Iran, dalam sebuah keluarga yang berpendidikan baik (Nasr S. H., Curriculum Vitae of Seyyed Hossein Nasr, 1990, hal. 1). Ibunya salah seorang dari keluarga yang berpendidikan sangat baik, yakni keluarga seorang ulama. Ayahnya adalah seorang dokter praktek yang ahli dalam pengobatan, baik pengobatan secara tradisional maupun modern. Ia juga seorang sarjana sastra ${ }^{33}$ dan seorang pendidik bangsa Persia yang sangat masyhur.

Nasr dibesarkan dalam tradisi dan locus ulama besar seperti Thabathaba'i, Hazbini dan lainnya. Dengan latar belakang semacam ini, tidaklah mengherankan apabila Nasr berkembang menjadi seorang intelektual yang selalu sarat dengan gagasan-

${ }^{32}$ Nina W. Syam, Filsafat Sebagai Akar Ilmu Komunikasi (Bandung: Simbiosa Rekatama Media, 2010), 48.

33 Seyyed Hossin Nasr, In Quest of the Eternal Sophia (The George Washington University, 1990), 133.

16 | TAJDID Vol. 17, No. 1, Januari - Juni 2018 
gagasan yang nampak diwarnai oleh ciri sufisme Persia. Pada jenjang selanjutnya, ia memperoleh pendidikan Barat modern. Dalam hal ini, ia menjadi cendikiawan muslim yang dibesarkan dalam dua tradisi : Islam "tradisional" dan Barat "modern". Hal ini seperti pengakuannya, ia sebenarnya hidup dalam ketegangan yang terus-menerus.

Seyyed Hossein Nasr belajar pendidikan dasar dan menegah di tempat kelahirannya, lebih ditekankan pada pendidikan klasik dan pendidikan keagamaan serta kesusastraan bangsa Persia. Pada awal pendidikan Nasr di Iran, telah diwarnai oleh banyaknya ketegangan antara pemikiran Barat dan Timur. Peradaban Barat yang sekuler telah berhasil mempengaruhi negeri-negeri muslim. Latarbelakang itulah sebabnya yang menjadi alasan kuat mengapa ayahnya sangat keras dalam mendidik Nasr untuk membekalinya dengan doktrindoktrin Islam secara kental sejak kecil. ${ }^{34}$

Setelah menyelesaikan pendidikan menengahnya, Nasr kemudian meneruskan pendidikan tingginya ke Amerika pada Massachussets Institute of Technology (MIT). Di sini, Nasr mempelajari lebih mendalam bidang ilmu fisika dan matematika teoritis dibawah bimbingan Bertrand Russel (w. 1970 M). Dari situ ia banyak mengetahui pemikiran tokoh modern. secara otodidak Nasr juga menekuni Ilmu-ilmu tradisional agama-agama Timur seperti tradisi Hindu, Budha dan khususnya tradisi pemikiran Islam. Pada saat yang sama, ia juga sangat tertarik dengan sejarah sains dan filsafat yang kebetulan diajarkan dosen tercintanya, Giorgio De Santillana ${ }^{35}$ (Nasr H. S., Science and Civilization in Islam, 1970, hal. vii). Dari perkenalannya dengan Giorgio, mengantarkannya pada karya-karya besar Dante. Melalui karya

34 Ali Maksum, Tasawuf Sebagai Pembebasan Manusia Modern; Telaah Signifikansi Konsep “Tradisionalisme Islam” Sayyed Hossein Nasr (Yogyakarta: Pustaka Belajar, 2003), 37.

35 Seyyed Hossin Nasr, Science and Civilization in Islam (New York: New American Library, 1970), vii.

TAJDID Vol. 17, No. 1, Januari - Juni 2018|17 
Dante inilah kemudian semakin terbuka baginya tradisi Barat serta kemegahannya. Nasr juga diberi informasi bahwa di Barat sedang terjadi perjuangan batin untuk mempertemukan titik pandang antara sains, filsafat dan agama.

Nasr sempat berjumpa dengan tokoh-tokoh lain, antara lain, G. Sarton, Sir Hamilton Gibb, W. Jaeger dan H.A. Wolfson dan setelah sempat pula sebelumnya berguru dengan Bertrand Russel tentang berbagai aliran filsafat Barat modern, yang intinya semua menjurus pada paham materialistik. Hal ini dikarenakan Nasr melanjutkan kuliah ke Harvard University untuk menekuni studi filsafat dan sejarah ilmu pengetahuan, dengan kajian utama dalam bidang Islamic Science and Philoshiphia. Di perguruan tinggi ini Nasr belajar sejarah dan pemikiran Islam kepada HAR. Gibb, sejarah ilmu pengetahuan kepada George Sarton dan belajar sejarah teologi serta filsafat kepada Hary Wolfson. Nasr berhasil meraih gelar Doktor (Ph.D) dalam bidang sejarah, sains dan filsafat Islam dari Harvard University pada tahun 1958, dengan desertasinya yang berjudul: An Introduction to Islamic Cosmological, dan berhasil diterbitkan dengan judul yang sama pada tahun $1964^{36}$.

Setelah mengantongi gelar Ph.D., Nasr kembali ke Iran dan mendapat kesempatan mengajar di Universitas Teheran. Ia memberi kuliah mata pelajaran Sejarah Sains dan Filsafat Islam. Pada tahun berikutnya, ia diangkat menjadi guru besar bidang sains dan filsafat Islam. Ia juga sempat menjadi dekan Fakultas Sastra Islam selama 4 tahun (1968-1972). Pada tahun 1962-1965 Nasr diangkat menjadi profesor tamu pada Harvard University. Ia juga merupakan seorang sarjana yang menduduki pimpinan Aga Khan Chair of Islamic Studies yang baru dibentuk di American University

36 Waryono Abdul Ghafur, "Seyyed Hossein Nasr: Neo Sufisme Sebagai Alternatif Modernisme", dalam A. Khudori Soleh, Pemikiran Islam Kontemporer (Yogyakarta: Penerbit Jendela, 2003), 383.

18 | TAJDID Vol. 17, No. 1, Januari - Juni 2018 
of Beirut (1964- 1965) ${ }^{37}$. Saat terjadi Revolusi Iran pada 1979 yang berakhir dengan tersingkirnya Reza Pahlevi, Nasr justru masih menjabat sebagai direktur Imperial Iranian, Academy of Philosophy, suatu jabatan paling bergengsi yang dapat mengantarkannya untuk menerima gelar kebangsawanan dari Sang Raja, rezim penguasa yang secara terus terang didukungnya. Namun akibat kedekatannya dengan pihak penguasa ini, Nasr masuk dalam daftar hitam (black list) yang disusun para aktivis gerakan yang menentang Syah, termasuk didalamnya Ali Syari'ati. Karena hal tersebut, meski pada awalnya Nasr bergabung dengan Ali Syariati di Husainiyah alIrsyad, Nasr akhirnya memilih keluar dari lembaga tersebut, di samping karena adanya perbedaan "ideologi" di antara mereka berdua $^{38}$.

Nasr banyak sekali menulis untuk jurnal-jurnal internasional, ia juga sering diundang untuk memberikan ceramah atau kuliah di universitas di berbagai Negara, seperti AS, Eropa, Negara-negara Timur Tengah, India, Jepang dan bahkan Australia. Nasr bahkan menjadi satu-satunya muslim dan orang Timur pertama yang mendapat kesempatan untuk menyampaikan pidato dalam Gifford Lecture, sebuah forum yang sangat bergengsi bagi kalangan teolog, filsuf, dan saintis Amerika dan Eropa sejak didirikan pada 1981, dalam kesempatan ini digunakan oleh Nasr untuk menyajikan beberapa aspek kebenaran yang terletak di jantung tradisi Timur dan di jantung semua tradisi. Hasil ceramahnya itu dipublikasikan dengan judul Knowledge and the Sacred. ${ }^{39}$

37 Waryono Abdul Ghafur, "Seyyed Hossein Nasr: Neo Sufisme Sebagai Alternatif Modernisme", dalam A. Khudori Soleh, Pemikiran Islam Kontemporer (Yogyakarta: Penerbit Jendela, 2003). 381.

38 Waryono Abdul Ghafur, "Seyyed Hossein Nasr, 382.

39 Waryono Abdul Ghafur, "Seyyed Hossein Nasr, 383.

TAJDID Vol. 17, No. 1, Januari - Juni 2018|19 


\section{Pemikiran Nasr tentang Tuhan, Manusia dan Akal}

Tradisi keagamaan monoteis menjadikan ketuhanan selalu menempati posisi teratas dari persoalan-persoalan keagamaan lainnya. Perkenalan awal Islam bagi pemeluknya dimulai dengan penegasan "Tidak ada Tuhan selain Allah" -yang merupakan pondasi paling dasar dalam beragama (Tauhid). Rumusan penegasan ini mencakup wilayah mengenai cara pandang manusia terhadap realitasnya. Sehingga nama Tuhan adalah "Allah", menempati posisi sentral dalam setiap tindakan dan pemikiran setiap muslim ${ }^{40}$ (Al-Faruqi, 1988, hal. 1). Kehadiran Tuhan mengisi kesadaran muslim dalam waktu kapan saja. Sehingga jika Nurcholish berargumen bahwa "Agama atau sikap keagamaan yang benar (diterima Tuhan) ialah sikap pasrah kepada Tuhan (QS.3:19). Perkataan “al-islam” dapat diartikan sebagai "agama Islam”, yakni, agama yang dibawa oleh Nabi Muhammad SAW. Tetapi dapat juga diartikan secara lebih umum, yaitu menurut makna asal atau generiknya, "pasrah kepada Tuhan", suatu semangat ajaran yang menjadi karakteristik pokok semua agama yang benar" ${ }^{\prime 41}$.

Oleh sebab itu Nasr menjelaskan bahwa setiap agama asli yang telah mencoba memberikan pengetahuan mengenai Keesaan Tuhan dan berbagai aspek Realitas Tak Terbatas-Nya. Berbeda halnya dengan agama-agama lain yang lebih menitikberatkan pada elemen tertentu dari Realitas tersebut, Islam justru memproyeksikan dan menggambarkan kepada manusia tentang ajaran keseluruhan Watak Tuhan yang memungkinkan bahasa

40 Isma’il Roji Al-Faruqi, Taubid (R. Astuti, Penerj.), (Bandung: Pustaka, 1988), 1.

${ }^{41}$ Nurcholis Madjid, Islam Doktrin dan Peradaban: Sebuab Telaab Krisis tentang Masalab Keimanan, Kemanusiaan, dan Kemodernan (Jakarta: Paramadina, 1992), 2.

20 | TAJDID vol. 17, No. 1, Januari - Juni 2018 
manusia untuk bisa memahaminya ${ }^{42}$. Nasr coba menjelaskannya dalam kalimat berikut:

Allah SWT, Realitas Tertinggi, Tuhan sekaligus Ketuhanan, transenden sekaligus imanen, sangat jauh sekaligus sangat dekat manusia, agung sekaligus pemurah. Dia Absolut, tak terbatas dan sumber segala rahmat. Dia asal mula dan akhir segala sesuatu. Dia adalah pencipta, pemelihara dan juga penghancur alam semesta, dalam arti Dia menentukan kehidupan dan kematian. Segala sesuatu kembali kepada-Nya. Semua kualitas positif yang kita dapati di alam semesta seperti kecantikan, kebaikan, dan kekuatan berasal dari-Nya, dan Dia bukan hanya sumber alam semesta tetapi juga sumber kualitas-Nya ${ }^{43}$.

Nasr menempatkan seluruh dimensi dari Realitas Ketuhanan tersebut pada pola hubungan bipolar, yang masing-masing kutub adalah setara dan saling meliputi. Dengan demikian, konsep eksistensial Tuhan dalam Islam mengatasi pertentangan, yang secara berhadapan berbeda. Artinya, mereka saling melingkupi dalam kesempurnaan Zat-Nya, sehingga nampak terasa sekali adanya prinsip al-jam' bayn al-addad (coincidentia oppositorum) menjadi dasar pondasi filosofis Nasr dalam memahami Realitas Tuhan. Tuhan bagi pemahaman Nasr tidak bisa dipahami kecuali dengan memadukan dua sifat yang berlawanan pada-Nya.

Nasr memberikan penjelasan, Tauhid -yang menjadi inti dari wahyu Islam, tidak hanya merupakan presupposisi Realitas Ilahi tapi juga mendominasi di setiap ekspresi-Nya. ${ }^{44}$ Tuhan ditunjukkan dengan banyak nama dalam al-Qur'an, tapi semua itu selalu mengacu pada satu nama yang tertinggi (al-ism al-a'zam), yakni

42 Seyyed Hossein Nasr, Knowledge and the Scred (Edinburgh : Edinburgh University Press, 1981), 161

43 Seyyed Hossein Nasr, Menjelajah Dunia Modern Bimbingan Untuk Kaum Muda Muslim (H. Tarekat, Penerj.) Bandung: Mizan, (1994), 34.

44 Seyyed Hossein Nasr. "GOD”. Dalam Seyyed Hossein Nasr (Penyunt.), Islamic Spirituality: Foundations (New York: Crossroad, 1987), 314.

TAJDID Vol. 17, No. 1, Januari - Juni 2018 |21 
"Allah" sendiri, sebagai nama zat Tuhan, sebagaimana sifat-sifatNya yang termuat dalam watak Ketuhanan Allah. Sedangkan Syahadab berisi ajaran utuh tentang Allah yang mengatasi relativitas, kemenduaan dan kemungkinan lain dari keIlahian dan berisi pengetahuan tentang Tuhan berdasarkan keesaan-Nya. Prinsip aljam' bayn al-addad menjadi pondasi dan penjelas terhadap bentuk keesaan (One-ness) Tuhan. Pada diri-Nya, Tuhan dipandang sebagai Yang Transenden, tapi di sisi lainnya, Tuhan sebagai zat-Nya adalah munazzah, bersih dari dan tidak dapat diserupakan dengan alam, jauh dari dan tinggi di atas segala sifat dan segala keterbatasan dan keterikatan. Sehingga, Tuhan tidak mungkin dapat digambarkan, tidak mungkin dapat dipikirkan bentuknya bahkan tidak dapat dilukiskan dengan sesuatu dalam akal. Hanya ada satu sifat yang bisa berlaku pada Tuhan, yakni sebuah keabsolutan yang dapat menghimpun sifat Tak Terbatas dan sifat Maha Sempurna milik-Nya.

Nasr menyatakan bahwa keabsolutan Tuhan dalam bahasa alQur'an justru merujuk pada keagungan Tuhan, sedangkan Ketidakterbatas Tuhan merujuk pada ke-jamal-an (KeindahanNya), adapun Kemahasempurnaan Tuhan justru merujuk pada Kamal (dalam bahasa Arab, juga disebut untuk menunjukkan makna kesempurnaan secara keseluruhan). Bila demikian, maka Tuhan, sebagai Yang Absolut, adalah sumber segala sesuatu yang maujud, Dia adalah Sumber dari realitas model dasar segala sesuatu, Dia adalah Sumber dari model dasar yang abadi (para sufi mengidentikkan ini sebagai al-a'yan al-thabithah), Tuhan adalah Sumber dan Asal-Usul segala kesempurnaan dan segala kualitas dalam penciptaan.

Tuhan melalui nama, sifat dan penampakan diri-Nya dalam bentuk berupa alam, disebut sebagai musyabbah (serupa dengan makhluk-Nya pada tingkat ekspresi tertentu). Tuhan sebagai mutajalli (menampakkan diri), mempunyai kesamaan dengan alam sebagai majla (lokus penampakan diri) dimana alam itu sendiri 
menajadi mazhar yang tak lain berupa Lokus penampakan. Walau kesamaan yang dipunyai itu hanya dalam prosentase yang paling kecil sekalipun.

Demikian itu, diperkuat oleh Nasr dengan adanya penjelasan mengenai Wajh Tuhan, sebagai berikut:

Wajh dalam kenyataan berarti sejumlah Nama dan Sifat Tuhan yang ada dalam dunia ciptaan, yang berarti bahwa aspek Realitas Ilahiah telah mewujud dalam penciptaan. Memang benar ada aspekaspek Ilahiah yang berada di atas dan di luar penciptaan dan yang tidak ada kaitannya dengan hukum penciptaan. Wajah Allah SWT benar-benar aspek Ilahiah yang mewujud dan berkaitan dengan penciptaan dan karena mencukup Nama dan Sifat Tuhan yang berhubungan dengan aksi kreatif serta eksistensi hukum penciptaan ${ }^{45}$.

Hubungan Tuhan dengan alam semesta tidak terbatas hanya sebagai permulaan segala sesuatu, melainkan juga pola hubungan Tuhan, manusia, dan alam semesta yang melngkapi satu dengan lainnya. Manusia menurut Nasr, dipandang sebagai jembatan antara langit dan bumi, instrumen yang menjadi perwujudan Kehendak Allah di muka bumi. Manusia sebagai sebuah bentuk kepercayaan Tuhan di muka bumi sebagai khalifatullah fi al-ardi, yang mempertanggungjawabkan segala tindakannya kepada Tuhan dan menjadi pemelihara bumi yang merupakan wilayah "kekuasaannya". Juga sebagai teofani dari Nama-nama dan Sifatsifat Tuhan, atau sebagai "Bayangan Tuhan". Adapun kebebasan personal manusia terletak pada penyerahan diri kepada kehendak Tuhan dan memurnikan diri sendiri ke tingkat yang lebih tinggi secara batin sehingga terbebaskan dari kondisi-kondisi eksternal, termasuk di dalamnya nafsu jasmaniah (nafs), yang menekankan

45 Seyyed Hossein Nasr, Menjelajah Dunia Modern: Bimbingan Untuk Kaum Muda Muslim, terj. Hasti Tarekat (Bandung: Mizan, 1994), 37.

TAJDID Vol. 17, No. 1, Januari - Juni 2018 |23 
dan membatasi kebebasan seseorang ${ }^{46}$ (Nasr S. H., "The Concept and Reality of Freedom in Islam and Islamic civilization", 1980, hal. 95). Manusia dipandang sebagai makhluk teomorfis, dirinya merefleksikan semua Nama dan Sifat Tuhan secara langsung dan sentral; tetapi sebenarnya ia bukanlah yang mutlak pada dirinya sendiri, khususnya dalam keadaannya yang sementara di dunia ini karena kenyataanya kualitas positif dalam bentuk apapun yang dimiliki manusia pada hakikatnya berasal dari Tuhan ${ }^{47}$.

Segala sesuatu, menurut Nasr, sebagai manifestasi prinsip Ilahi Tertinggi yang mengatasi semua determinasi -bahkan wujud, determinasinya yang pertama. Semua wujud dalam manifestasi, yang nampak dan juga yang tak nampak, dihubungkan dengan pusat ini menurut derajat dimana wujud tersebut mencerminkan Akal dan juga menurut eksistensinya. Akal setiap wujud adalah sebuah ikatan langsungnya dengan Akal Alam Raya-Logos atau Kalam, tempat dimana semuanya dijadikan. Derajat wujud tiap makhluk adalah refleksi dari Wujud Murni pada suatu tingkat eksistensi kosmis; berkat refleksi inilah maka suatu wujud berupa sesuatu dan bukan tidak ada ${ }^{48}$. Nasr menekankan sebagai berikut:

"Jika prinsip Ilahi dilambangkan dengan sebuah titik, maka relasi berbagai wujud dengan-Nya sebagai Wujud Murni, adalah bagaikan berbagai lingkaran konsentris dengan satu titik pusat, sedangkan relasi wujud itu dengan titik pusat tersebut sebagai Akal adalah seperti relasi berbagai radius lingkaranlingkaran tersebut ke titik pusat itu. Jadi kosmos adalah seperti sarang laba-laba: tiap bagiannya terletak pada sebuah lingkaran, yang merupakan "refleksi titik pusat" dan yang menghubungkan eksistensi bagian

46 Seyyed Hossein Nasr, "The Concept and Reality of Freedom in Islam and Islamic civilization”. Dalam Resenbaum (Penyunt.), The Philosophy of Human Rights (Westport, 1980), 95.

${ }^{47}$ Seyyed Hossein Nasr, Islam dan Krisis Lingkungan (I. A. Fauzi, Penyunt.) ISLAMIKA, 3 (Januari-Maret, 1994), 10.

48 Seyyed Hossein Nasr, Science and Civilization in Islam, (New York: New American Library, 1970), 338.

24 | TAJDID vol. 17, No. 1, Januari - Juni 2018 
tersebut terhadap Wujud; pada saat yang sama tiap bagian dihubungkan langsung ke pusat oleh sebuah radius, yang melambangkan relasi antara "akal" bagian tersebut dengan Akal Semesta atau Logos 49

\section{Kesimpulan}

Sebagai tatanan realitas kesemestaan, hubungan Tuhan dengan ciptaan-ciptaan-Nya secara dialektis tidak hanya menandakan tentang persoalan agama an sich. agama sebagai suatu proses historis interaksi manusia dalam menggapai Yang Suci. Ketiga konsepsi di atas milik pemikiran Al-Kindī dan Nasr bahwa Tuhan, manusia dan akal pada gilirannya bermuara pada cara pandang tentang realitas kesemestaan secara keseluruhan Tuhan manusiawahyu-alam semesta.

\section{Daftar Pustaka}

Aceh, Abu Bakar. (1982). Sejarah Filsafat Islam. Sala: Ramadhani. Al-Alhwani, Ahmad Fuad. (1985). Filsafat Islam, Terj. Sutarji Caulzoum Bakhri. Jakarta: Pustaka FirdausAl-Faruqi, I. R. (1988). Tauhid. (R. Astuti, Penerj.) Bandung: Pustaka.

Atiyah, George N. (1983). Al-Kindi Tokoh Filosof Muslim.

Bandung: Penerbit Pustaka.

Basri, H. (2013). Filsafat Islam, . Jakarta: Direktorat Jenderal Pendidikan Islam Kementerian Agama Republik Indonesia.

Fakhry, Majid. (2002). Sejarah Filsafat Islam, Bandung: Mizan.

Gazalba, Sidi. (1973). Sistematika Filsafat. Buku III. Jakarta: Bulan Bintang.

Ghafur, Waryono Abdul. (2003) "Seyyed Hossein Nasr: Neo Sufisme Sebagai Alternatif Modernisme", dalam A. Khudori Soleh, Pemikiran Islam Kontemporer. Yogyakarta: Penerbit Jendela.

Hanafi, A. (1962). Theologi Islam. Yogyakarta: Sumbangsih.

${ }^{49}$ Seyyed Hossein Nasr, Science, 338.

TAJDID Vol. 17, No. 1, Januari - Juni 2018|25 
Hanafi, Ahmad. (1969). Pengantar filsafat Islam. Jakarta: Bulan Bintang.Hidayat, K., \& Nafis, M. W. (1995). Agama Masa Depan: Persepektif Filsafat Pernial. Jakarta: Paramadina.

Kuswanjono, A. (2006). Ketuhanan Dalam Telaah Filsafat Perenial: Refleksi Pluralisme Agama di Indonesia. Yogyakarta: Badan Penerbit Filsafat UGM.

Madjid, N. (1992). Islam Doktrin dan Peradaban: Sebuah Telaah Krisis tentang Masalah Keimanan, Kemanusiaan, dan Kemodernan. Jakarta: Paramadina.

Murtiningsih, Wahyu. (2013). Para Filsuf dari Plato sampai Ibnu Bajjah. Jogjakarta: IRGiSoD.

Maksum, Ali. (2003). Tasawuf Sebagai Pembebasan Manusia Modern; Telaah Signifikansi Konsep "Tradisionalisme Islam” Sayyed Hossein Nasr. Yogyakarta: Pustaka Belajar.

Nasr, H. S. (1970). Science and Civilization in Islam. New York: New American Library, .

Nasr, H. S. (1990). In Quest of the Eternal Sophia. The George Washington University.

Nasr, S. H. (1980). "The Concept and Reality of Freedom in Islam and Islamic civilization". Dalam Resenbaum (Penyunt.), The Philosophy of Human Rights. Westport.

Nasr, S. H. (1987). “GOD”. Dalam S. H. Nasr (Penyunt.), Islamic Spirituality: Foundations,. New York: Crossroad.

Nasr, S. H. (1990). Curriculum Vitae of Seyyed Hossein Nasr. The George Washington University.

Nasr, S. H. (1994, Januari-Maret). Islam dan Krisis Lingkungan. (I. A. Fauzi, Penyunt.) ISLAMIKA, 3.

Nasr, S. H. (1994). Menjelajah Dunia Modern Bimbingan Untuk Kaum Muda Muslim. (H. Tarekat, Penerj.) Bandung: Mizan.

Nasr, Seyyed Hossein \& Oliver Leamen. 2003. Ensiklopedi Tematis Filsafat Islam. (ed). Bandung: Mizan.

Nasution, H. (1973). Falsafat dan Mistisisme Dalam Islam. Cet. 1. Jakarta: Bulan Bintang.

26 | TAJDID vol. 17, No. 1, Januari - Juni 2018 